\title{
DESICCATION RESISTANCE IN ARCOBACTER BUTZLERI
}

\author{
Laura Otth; Myra Wilson; Heriberto Fernández*
}

Institute of Clinical Microbiolog, Universidad Austral de Chile. Valdivia, Chile

Submitted: June 07, 2001; Returned to authors for corrections: August 03, 2001; Approved: December 14, 2001

\section{SHORT COMMUNICATION}

\begin{abstract}
The desiccation resistance of $A$. butzleri was studied. Two, 3 and 4 of the strains did not resist desiccation for more than 2,12 and $36 \mathrm{~h}$, respectively. Two strains resisted desiccation for $\geq 48 \mathrm{~h}$. A. butzleri seems to be more resistant to desiccation than the classical enteropathogenic Campylobacter species.
\end{abstract}

Key words: Arcobacter butzleri, Campylobacteraceae, desiccation resistance.

The genus Arcobacter comprises spirally, curved, Gram negative rods divided into four species (A. nitrofrigilis, A. cryaerophilus, $A$. butzleri and $A$. skirrowii) which were previously considered as members of the genus Campylobacter (6).

A. butzleri and A. cryaerophilus have been associated with infectious processes in animals and human beings. A. butzleri seems to be more frequent than $A$. cryaerophilus, being considered as a zoonotic and emerging bacterium that could be associated with bacteremia and human diarrheic illness. It has been also isolated from food of animal origin, especially from poultry retails, carcasses and offal, as well as from water bodies and sewage $(4,6)$. Their growth requirements, and their viability in water are known $(4,5,6)$. However, other characteristics related to their survival capacity under environmental conditions, such is their resistance to desiccation, remain unknown.

The aim of this study was to establish the desiccation resistance in 11 strains of $A$. butzleri isolated from commercial chicken livers. All of them were freshly isolated strains.

The desiccation resistance, in absence of organic matter, was determined by means of the method proposed by Berger and Döring to study Neisseria sensitivity to drying (1) and later adapted to establish Campylobacter desiccation resistance (3). In brief, several pieces of sterile gauze $\left(1 \mathrm{~cm}^{2}\right)$ were imbibed separately with $1 \mathrm{ml}$ of a $48 \mathrm{~h}$ culture $\left(10^{6} \mathrm{cfu} / \mathrm{ml}\right)$ of each strain in tryptose broth and allowed to dry at $37^{\circ} \mathrm{C}$ in half-opened
Petri dishes. During a first $12 \mathrm{~h}$ period, starting from time 0 and every $2 \mathrm{~h}$, one single piece of gauze of each strain was introduced in tubes containing $10 \mathrm{ml}$ of tryptose broth and incubated at $24^{\circ} \mathrm{C}$ for $48 \mathrm{~h}$ under aerobic conditions. During the second period, that ranged from 12 to $48 \mathrm{~h}$, the gauze pieces were seeded into the tryptose broth tubes every $12 \mathrm{~h}$. After the incubation period, the tubes were examined looking for turbidity and then, in order to confirm survival capacity and discard eventual contamination during the desiccation period, they were subcultered on blood agar plates that were incubated in the same conditions mentioned above.

As shown in Fig. 1, desiccation resistance of the 11 strains under study ranged from 2 to $\geq 48 \mathrm{~h}$. The less resistant strains (2) survived for less tha 2 hours, 3 strains were viable after 12 and two after 36 hours. The remaining 2 strains resisted desiccation for a period longer than $48 \mathrm{~h}$. These results suggest that desiccation resistance in $A$. butzleri could be strain dependant, as it was observed in Campylobacter jejuni and $C$. coli (3). The phylogenetic similarities observed between Arcobacter and Campylobacter (6) suggested that a similar behaviour in resistance to desiccation would also be expected. However, since 6 of the 11 strains resisted desiccation for $12 \mathrm{~h}$ or more, we could conclude that A. butzleri seems to be more resistant than the classical enteropathogenic Campylobacter species, whose desiccation resistance ranged from 2 to 10 hours (3). Similar results were found by Collins at al with respect to

* Corresponding author. Mailing address: Institute of Clinical Microbiology. Universidad Austral de Chile. Casilla 567. Valdivia, Chile. Tel. (+56) 63-

214377, Fax: (+56) 63-293300. E-mail: hfernand@uach.cl 


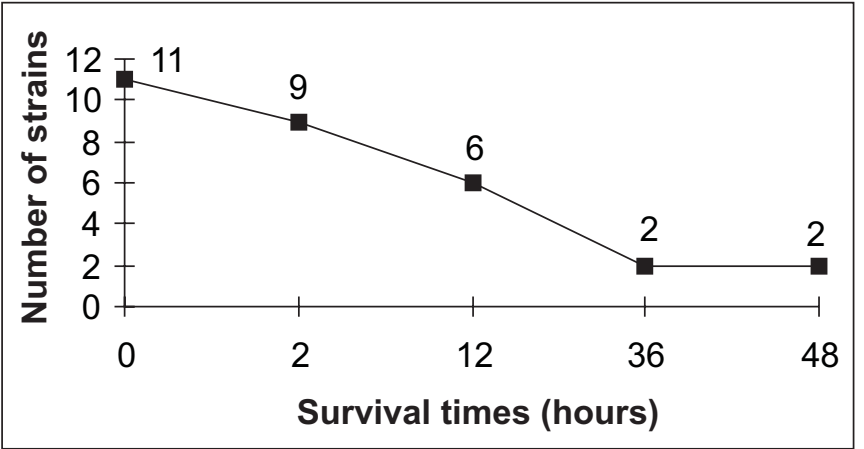

Figure 1. Survival rates of 11 strains of A. butzleri exposed to desiccation.

the ability of $A$. butzleri to survive irradiation under vacuum in ground pork (2). The establishment of A. butzleri desiccation behaviour is important in defining food handling conditions. The information presented here is also important with respect to the transport of clinical specimens and should be taken into account in the maintenance of cultures in the laboratory and while studying the epidemiology of Arcobacter infections in humans and animals, especially if this bacteria could be present in food of animal origin used for human consumption.

\section{ACKNOWLEDGMENTS}

This work received financial support from Grants FONDECYT 1980920 and DID-UACH S-200133.

\section{RESUMO}

\section{Resistência de Arcobacter butzleri à dessecação}

A resistência de Arcobacter butzleri à dessecação foi determinada. Duas, 3 e 4 amostras não resistiram a dessecação por mais de 2, 12 e $36 \mathrm{~h}$, respectivamente. Duas amostras resistiram a dessecação por $\geq 48$ h. A. butzleri seria mais resistente que as espécies enteropatogênicas clássicas de Campylobacter.

Palavras-chave: Arcobacter butzleri, Campylobacteraceae, resistência à dessecação.

\section{REFERENCES}

1. Berger, U.; Döring, M.T. Zur Resistenz der humanen Neisseria-Arten gegen Austrocknung. Arch. Hyg. Bakt., 6: 556-559, 1969.

2. Collins, C.I.; Murano, E.A.; Wesley, I.V. Survival of Arcobacter buitzleri and Campylobacter jejuni after irradiation treatment in vaccum-packaged ground pork. J. Food. Prot. 59: 1164-1166, 1996.

3. Fernández, H.; Vergara, M.; Tapia, F. Desiccation resistance in thermotolerant Campylobacter species. Infection, 13: 197, 1985 .

4. Lastovica, A.J.; Skirrow, M.B. Clinical significance of Campylobacter and related species other than Campylobacter jejuni and C. coli. In: Nachamkin, I.; Blaser, M.J. (eds). Campylobacter $2^{\text {nd }}$ Edition. ASM Press, Washington, D.C., 2000, p.89-120.

5. Rice. E.W.; Rodgers, M.R.; Wesley, I.V.; Johnson, C.H.; Tanner, S.A. Isolation of Arcobacter butzleri from ground water. Lett. Appl. Microbiol., 28: 31-35, 1999.

6. Vandamme, P. Taxonomy of the Family Campylobacteraceae. In: Nachamkin, I.; Blaser, M.J. (eds). Campylobacter $2^{\text {nd }}$ Edition. ASM Press, Washington, D.C., 2000, p.3-26. 